\title{
CENTER-PERIPHERAL DIFFERENCES IN LIFE EXPECTANCY IN RUSSIA: A REGIONAL ANALYSIS
}

\author{
ALEKSEY SHCHUR, SERGEY TIMONIN
}

\begin{abstract}
Elevated mortality (compared with the West) and significant spatial differences in life expectancy are serious challenges facing Russia. The goals of improving Russians' health and increasing their life expectancy by reducing inequality in mortality between regions and settlements are closely intertwined with the goals of spatial development of Russia, aimed at reducing interregional differences in the quality of life.
\end{abstract}

This paper presents an assessment of the scope and dynamics of changes in mortality differences between the 'center' and the 'periphery' in 67 regions of Russia, which are home to three-quarters of the country's population. The selected research period - 2003-2018 - is characterized by a steady increase in life expectancy at birth (LE) in Russia. Using unpublished data from Rosstat for cities, we estimated life expectancy at birth in 67 regional centers and in the rest of the regions ('periphery'). Depending on the magnitude of the differences in LE and the dynamics, we identified 6 types of regions. For those regions with a LE gap between center and periphery larger than the average, the decomposition method was applied, which made it possible to determine the key age groups and causes of death responsible for such high differences.

In 36 regions of Russia classified as types I-III, the center-peripheral gap exceeded the average Russian level, while only in six regions in 2003-18 was there a tendency towards a reduction in the size of this gap. The decomposition results showed that elevated mortality of males in the periphery is due to a higher mortality rate at working age from external causes of death, especially from traffic accidents, homicides and suicides, as well as from 'alcoholic' causes of death; females in the periphery suffer from higher mortality rate at older ages from chronic non-communicable diseases.

Despite the seemingly 'objective' nature of the mortality differences between the center and the periphery (the advantage of the former being due to the socio-demographic characteristics of its residents and the educational structure of the population, as well as to selective migration), the positive experience of other countries shows that effective public health policies can substantially reduce the degree of spatial inequality in mortality even if significant heterogeneity in the level of socio-economic development remains.

Key words: life expectancy, mortality, Russian regions, regional capitals, center and periphery.

\section{INTRODUCTION}

The administrative centers of Russia's regions, concentrating a significant part of the country's human, institutional, financial and political capital, are strikingly different in terms of the level of economic and social development from the surrounding territories (Leksin 2009).

\footnotetext{
AleXey Shchur (aschur@hse.ru), National Research University Higher School of Economics, Russia.

SERgey Timonin (stimonin@hse.ru), National Research University Higher School of Economics, Russia.

THE ARTICLE WAS PREPARED AS A RESULT OF RESEARCH CARRIED OUT WITHIN THE FRAMEWORK OF THE BASIC RESEARCH Program of the National Research University Higher School of Economics (HSE University).
}

THE ORIGINAL ARTICLE IN RUSSIAN WAS PUBLISHED IN DEMOGRAPHIC REVIEW IN 2019, 7(3), 108-133.

DOI: $10.17323 /$ DEMREVIEW.V7I3.11638 
The period after the collapse of the USSR is characterized by an increase in spatial polarization between the "center", both at the level of the entire country, represented by the Moscow metropolitan region, and at the level of the subjects of the federation, represented by the regional capitals, and a vast "periphery", both external (poorly developed areas of the North, Siberia and the Far East) and "internal", defined in each region according to its position in relation to the "center"1 (Nefedova, Treyvish 2020). Spatial polarization affects various aspects of life of the population of Russia. One of the most important, in our opinion, is the issue of spatial inequality of Russian mortality. Not without reason has it been noted that it is precisely the differentiation of population groups in terms of mortality that so accurately characterizes the level of socio-economic inequality in a society (Sen 1998).

The study of geographical differences in mortality in Russia has always been the focus of attention of domestic demographers, geographers and social hygienists (Novoselsky 1911; 1916). In the 1970s and 1980s, based on data collected around the time of the census, it was shown that life expectancy decreases as one moves across Russia from south to north and from west to east (Andreev 1979; Shkolnikov 1987). The lowest mortality rates were observed in the North Caucasus, in the Chernozem zone and in certain regions of the Volga region, and the highest in the North of European Russia, Eastern Siberia and the Far East. This pattern has been called the "southwest/northeast mortality gradient". Moreover, this phenomenon has turned out to be strikingly stable, despite significant fluctuations in mortality in Russia from the mid-1980s to the early 2000s (Vasin, Costello 1997).

The current stage of sustainable growth in life expectancy, the beginning of which is usually attributed to 2003-2005 (Vishnevsky, Shchur 2019), includes all regions of the country, (Timonin et al. 2017; Zakharov 2017) thus posing a logical question: is the period of growth in life expectancy accompanied by a reduction in interregional inequality in mortality? Responding to this question, Timonin et al. found that interregional variance, one of the quantities making it possible to quantify spatial differences in life expectancy, has remained virtually unchanged since 2005. However, the decomposition of changes in this measure of inequality by age shows that, in terms of mortality in childhood and working age, Russian regions are converging, while for older ages, on the contrary, there is a pattern of divergence, primarily due to a more rapid decline in mortality among the elderly population in Moscow and St. Petersburg (Timonin et al. 2017).

The special, privileged position of Moscow and St. Petersburg on the "mortality map" of Russia was first identified in the late 1990s and continued to grow throughout the 2000s (Andreev, Kvasha, Kharkov 2006; Papanova, Shkolnikov Timonin 2019). Probably, an important role in this was played by the increasing political and economic role of Moscow and, to a lesser extent, of St. Petersburg starting in the early 2000s. The consequences of this role include, among other things, a significant migration inflow to these centers and their regions, an overconcentration of human capital in them, and a higher standard of living, including greater spending on health care - all factors directly affecting life expectancy (Marmot 2005). At the same time, due to limited data, the study of geographic inequality in mortality in Russia until very recently concerned only

\footnotetext{
${ }^{1}$ Here and further in the text, "centers" will mean the administrative centers of the constituent entities of the Russian Federation, and "periphery" - the rest of the territory of the constituent entities.
} 
the highest level of the administrative-territorial division. As a consequence, much of the centerperipheral differences in mortality rates remained hidden from researchers (Timonin et al. 2020).

Having access to data on the distribution of deaths by sex, age and cause of death in regional centers other than just Moscow and St. Petersburg made it possible for us to estimate life expectancy at birth for nearly all capitals of Russia's oblasts, territories and republics, as well as to calculate some other indicators characterizing the epidemiological patterns of mortality in them.

The aim of the study is to assess changing trends in life expectancy of the population of regional centers and the other parts of Russian regions (the periphery) in the context of a nationwide decline in mortality rates observed since 2004. How great is the advantage of regional capitals in life expectancy over "their regions"? How has it changed over the past 15 years? How do regions differ in the magnitude and direction of changes in the center-peripheral inequality in mortality? In what age groups and from what causes of death does mortality make the greatest contribution to the differentiation of life expectancy between regional centers and the rest of the territory of the regions? In this study, we have tried to answer these and some other questions.

\section{DATA AND METHODS}

The Federal State Statistics Service of Russia (Rosstat) does not publish estimates of life expectancy for Russian cities other than Moscow, Saint Petersburg and - since 2015 - Sevastopol. However, Rosstat develops tables with the distribution of deaths by sex, age and cause of death for all Russian cities with a resident population of over 100 thousand people, and also estimates the average annual population by sex and one-year age groups. Based on these data, abridged (up to age 85+) life tables were constructed separately for men and women, and estimates of life expectancy at birth $\left(e_{0}\right)$ for 2003-2018 were obtained for 67 Russian regional capitals.

In addition to Moscow, St. Petersburg and the Moscow and Leningrad regions, as well as the Republic of Crimea and Sevastopol, our study excluded regions whose capitals in 2003 were cities with a population of less than 100 thousand people (Chukotka and the Yamalo-Nenets Autonomous Okrug, the Magadan Region, Jewish Autonomous Region and the Altai Republic) ${ }^{2}$. Also excluded were 6 republics of the North Caucasus Federal District for which there are reasonable concerns regarding the quality of demographic data, primarily estimates of the resident population and the completeness of death registration (Andreev 2012; Mkrtchyan 2012). Nevertheless, in the regions covered by the study, in 2018 there lived almost 110 million people, or about $3 / 4$ of the total population of the country.

Data on the number and age of deaths, as well as on the average annual population for 67 regions whose centers are the selected cities, were taken from the Russian Fertility and Mortality Database of the Russian School of Economics (RusFMD) (Russian School of Economics 2019). By subtracting one dataset (by city) from another (by region), the corresponding estimates

\footnotetext{
${ }^{2}$ Exceptions are the Khanty-Mansi Autonomous Okrug (where Surgut was chosen as the "center", and not the formal capital, Khanty-Mansiysk) and NAO (the Nenets Autonomous Okrug), in this study considered together with the Arkhangelsk region.
} 
of the number of deaths were obtained for 67 regions without their centers; for new units - regions without centers (periphery) - we also calculated the values of $e_{0}$.

Depending on the 2011-2018 average size of the gap in $e_{0}$ between the regional center and the rest of the region, all regions were divided into two types: regions in which the gap between centers was higher than the average for all regions (types I-III), and those in which it was lower (types IV-VI). Next, we analyzed the dynamics of the gap for 2003-2018. In accordance with these, each region was assigned to one of three types: regions where there was a tendency towards an increase in the center's advantage (that is, there was a divergence in $e_{0}$ between the center and the rest of the region); regions where the gap remained approximately at the same level (no statistically significant trend was observed) and regions where the gap was decreasing (i.e. convergence took place). Thus, the combination of these two characteristics allowed us to identify 6 types of regions (Appendix table).

For the first three types of regions (with a gap above the average for the entire sample), we applied the decomposition method (Andreev 1982) at one time point (in 2018) to identify which age groups and causes of death determine the center's advantage over the periphery in life expectancy at birth. For the first three types of regions, standardized mortality rates were also calculated according to the 1976 European population standard for the main classes and groups of causes of death separately in regional centers and beyond.

\section{ON THE TEMPORAL COMPARABILITY OF ESTIMATES OF THE POPULATION SIZE WITHIN REGIONS}

There are two main sources of information on the size and age-sex structure of the population in Russia: population censuses, which are the main source of data, and vital statistics (registration of demographic events such as births, deaths, change of permanent residence, i.e. migration, etc.) to estimate the size and composition of the population in the intercensal period. Overestimation of the population in some territories and underestimation in others in the intercensal period occurs mainly due to the migration component. Overestimation or underestimation of the official population size, including at certain ages, entails a distortion in the value of life expectancy due to the unreliability of the denominator used to calculate the age-specific mortality rates.

The share of the population living in the centers of the regions in the entire population increased throughout the study period (Figure A1 of the Appendix). The sharp jump in the share of the population between 2010 and 2011, associated with the traditional adjustment of the population size carried out according to the results of the 2010 All-Russian Population Census, stands out strongly. This means that the actual population size in most regional centers turned out to be higher than estimated (mainly due to underreporting of migration), while in other settlements, on the contrary, it was lower than estimated (Rosstat 2012). Since the previous population census in Russia took place in 2002, on the eve of the period under consideration, with each subsequent year the accumulated error in estimating the population size only increased, reaching a maximum in 2010 .

By retrospective extrapolation of the linear trend of growth in the share of centers in 2011-2018, we obtained estimates of the population size in the centers and in the rest of the regions 
for 2003-2010, adjusted for the results of the 2010 census $^{3}$. It will be shown below what effect the undercounting of the population in the centers and, accordingly, overcounting in the rest of the regions had on the magnitude and dynamics of the gap in $e_{0}$ between them.

\section{TYPOLOGY OF RUSSIAN REGIONS DEPENDING ON THE SCOPE AND DYNAMICS OF THE CENTER-PERIPHERAL GAP IN LIFE EXPECTANCY}

In 2003-2018 life expectancy at birth in regional centers exceeded the corresponding indicator in other settlements by 1.8-2.8 years, depending on the calendar year (Figure 1). The fastest growing gap in $e_{0}$ between the center and the periphery was recorded in 2004-2005, when it increased by 0.7 years. It was during this period, as Timonin et al. (2017) showed, that the level of interregional inequality in mortality in Russia was at its highest since the 1970s. It can be assumed that the regional centers were at the forefront of the decline in the mortality rate in Russia in the 2000s, since the transition to a steady growth of $e_{0}$ in them began in 2003, whereas in the rest of the settlements this did not happen earlier than 2006.

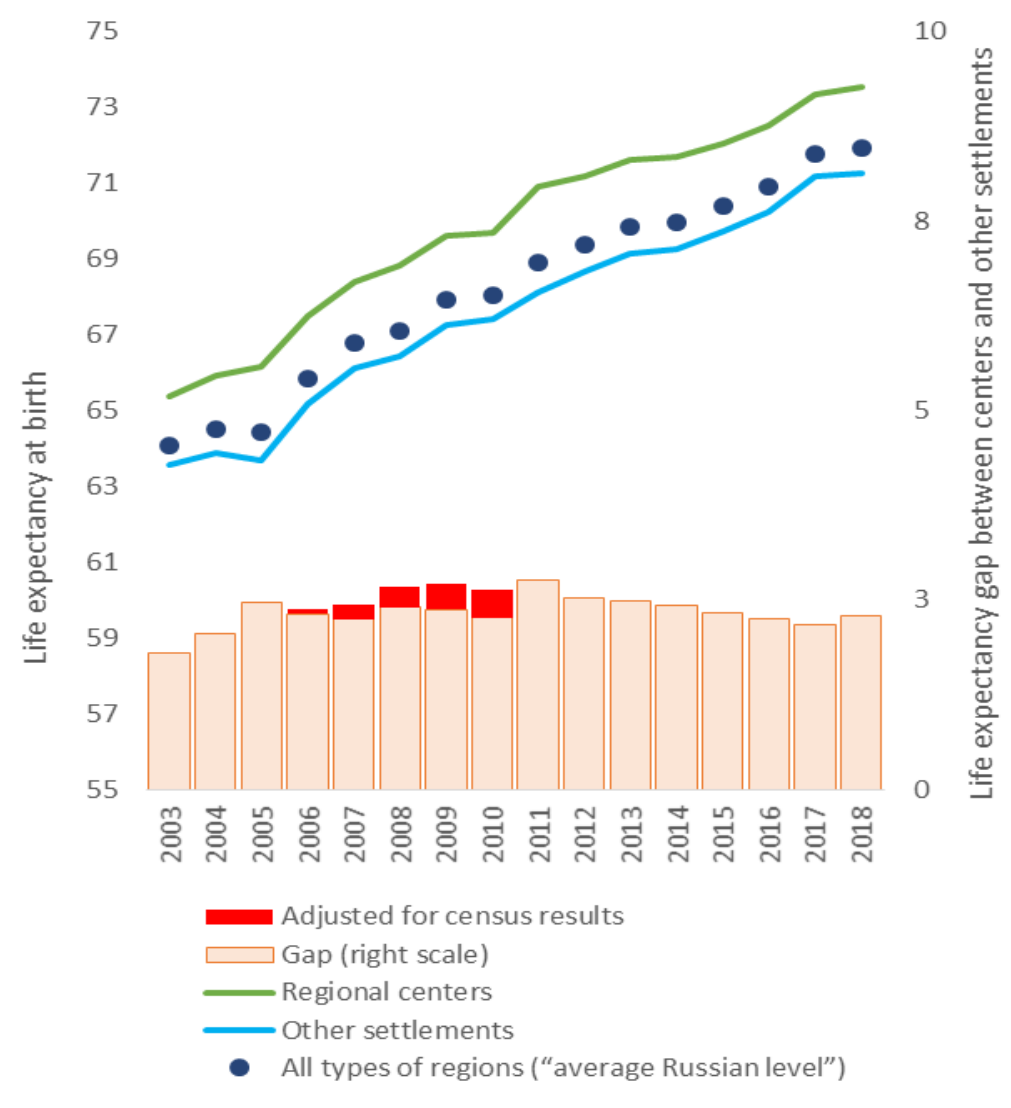

Figure 1. Life expectancy $\left(e_{0}\right)$ at birth in regional centers and other settlements of regions (left scale) and the corresponding gap in $e_{0}$ between them (right scale), in years, 2003-2018

\footnotetext{
${ }^{3}$ Officially, Rosstat makes a retrospective recalculation of the population size only at the level of regions of the Russian Federation.
} 


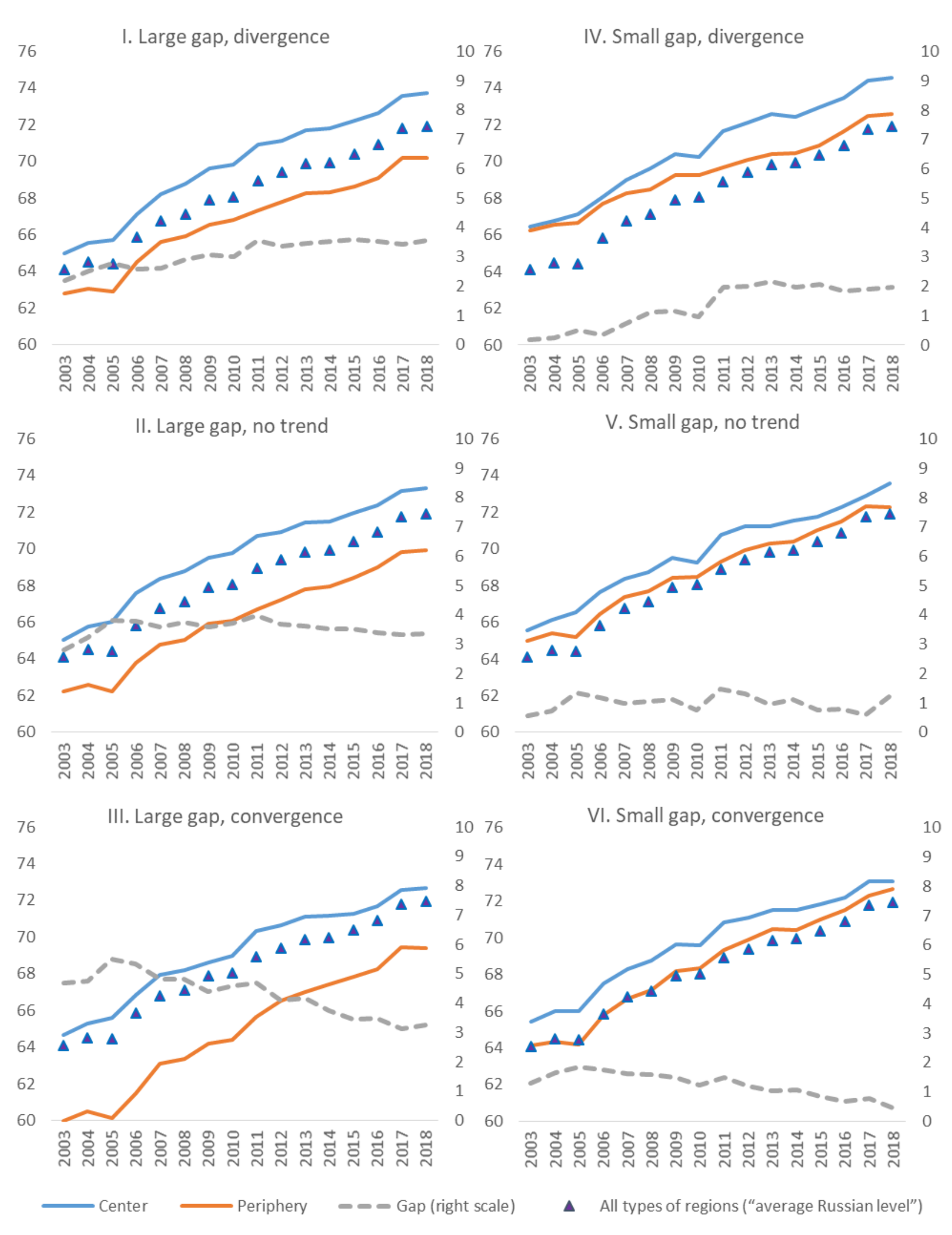

Figure 2. Life expectancy at birth in the centers and at the periphery and the magnitude of the gap between them (right scale) by types of regions, in years, 2003-2018

In 2007-2010 the gap remained at about the same level according to data unadjusted for the census, but according to adjusted data continued to widen until 2011, with the difference 
reaching 0.4 years for 2010. After 2011, life expectancy outside the regional centers began to grow rapidly, resulting in a trend towards convergence (the gap in $e_{0}$ narrowed from 2.8 years in 2011 to 2.2 in 2017) which, however, was interrupted in 2018. Thus, the period under consideration can be divided into two stages: the first is an increase in the advantage of the centers in life expectancy in 2003-2011, followed by the second stage, a decrease in the differences in $e_{0}$ between them and the rest of the settlements.

However, analysis for individual regions showed a significant degree of heterogeneity in the level and dynamics of changes in the gap in life expectancy between the centers and the periphery. Based on these two parameters (the size of the gap and its dynamics), we have identified 6 types of regions (the composition of each selected type is presented in the Appendix table). In 22 regions, the center's lead over the rest of the region in 2003-2018 increased significantly, albeit from different initial levels, while in 17 regions, on the contrary, the gap narrowed, and in the remaining 28 regions there was no clear trend.

Figure 2 for each type of region (I-VI) shows the values of $e_{0}$ in the centers and at the periphery and the gap between them, and all the graphs show the life expectancy curve for Russia as a whole ("all types of regions")

As can be seen from Figure 2, the growth in life expectancy in 2003-2018 took place in all types of regions, both in their centers and on the periphery. In types I and IV of the regions (large and small gap; divergence), the growth rates of $e_{0}$ in the centers outstripped those in the periphery. Type I, with a significant and growing center-peripheral gap, includes the Baikal macroregion (Irkutsk Oblast, the Republic of Buryatia and the Trans-Baikal Territory), as well as the Republics of Tuva and Yakutia, which form a single megacluster in the east of the country; the Sakhalin Region in the Far East, as well as regions along the Trans-Siberian Railway - Sverdlovsk, Tyumen (without districts), Omsk and Novosibirsk regions. In the west of the country, this type is represented by the Arkhangelsk, Kursk and Rostov regions, and the Republics of Komi and Mari El (Figure 3). Life expectancy in this type of region is lower than the national average, primarily due to the high mortality rate in the periphery ${ }^{5}$.

In type IV regions, on the contrary, are observed the highest values of life expectancy (Figure 4). Belgorod, Voronezh, Volgograd, Astrakhan and Murmansk regions and the Republics of Tatarstan and Bashkiria belong to this type. All these regions, except for Murmansk region, are characterized by a low mortality rate in the centers with a relatively favorable, in general, state of affairs in the periphery. Nevertheless, they clearly show a tendency for the periphery to lag behind the centers in terms of life expectancy.

Regions of type II, with a significant center-peripheral gap but without a statistically significant trend towards divergence or convergence, geographically "complement" regions of type I, being concentrated in the Far East (Primorsky, Khabarovsk Territories, Amur Region),

\footnotetext{
${ }^{4}$ Hereinafter, we are talking about Russia as a part of the 67 studied regions (excluding the capital regions and the republics of the North Caucasus).

5 The exception is the Rostov region, where a large center-peripheral gap is a consequence primarily of the low mortality rate in Rostov-on-Don (one of the lowest among regional capitals), together with a state of affairs on the periphery which, while on the whole mediocre, is far from the worst.
} 
in Siberia (Krasnoyarsk Territory, Republic of Khakassia, Kemerovo and Tomsk regions), in the Ural (Republic of Udmurtia, Kurgan, Orenburg and Chelyabinsk regions) and Volgo-Vyatka (Chuvashia, Kirov region in its eastern part) economic regions, in the north of European Russia (the Republic of Karelia) and in the center of the country, Vladimir region. Like the first, the second type too is characterized by a high mortality rate in the periphery, and the $e_{0}$ curves for the two types on the graph (Figure 4) are almost identical and lie below the average Russian level. The main difference between the two types is the slower growth rates of $e_{0}$ in the centers of type II regions compared to type I, which predetermined the difference between them in the trajectory of the center-peripheral discontinuity.

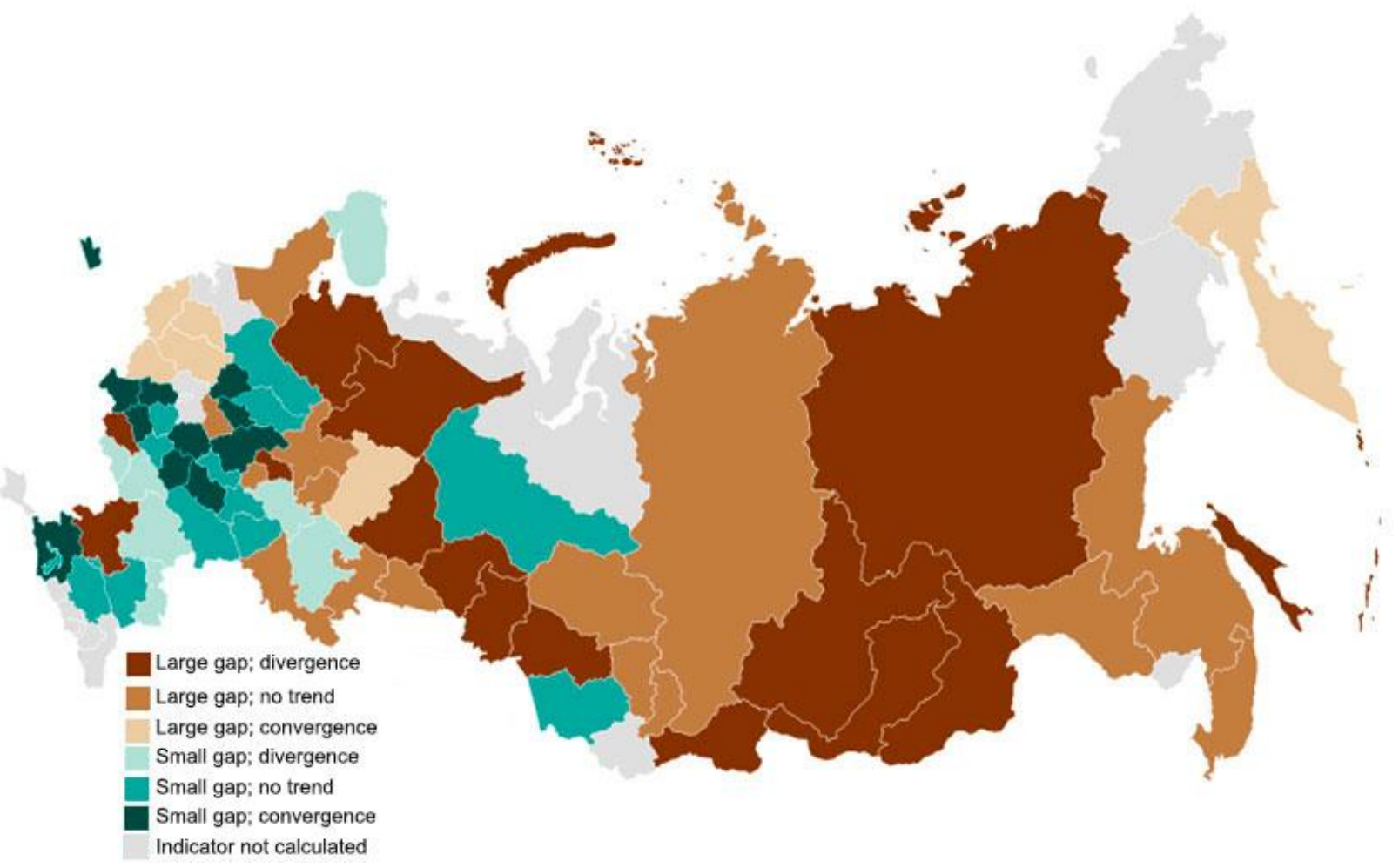

Figure 3. Types of regions depending on the size of the gap in life expectancy between the regional capital and the rest of the settlements and the dynamics of the gap, on average, 2003-2018

The smallest type, both in composition (6 regions) and in terms of population (6.4 million people), is the third. It is formed by a compact cluster in the north-west of the European part of the country (Pskov, Novgorod, Tver, Smolensk Regions), with the Perm and Kamchatka Territories also included in it. This type is characterized by the lowest $e_{0}$ values both in the center and at the periphery. Nevertheless, having shown a significant reduction in the center-peripheral gap in life expectancy, type III also showed the highest rate of decline in mortality in 2003-2018 among all types of regions (Figure 4). So, while in 2003 its lag behind type I regions and Russia as a whole was 1.3 and 2.4 years, in 2018 it decreased to 0.2 and 1.3 years, respectively.

The fifth (small gap; no trend) and sixth (small gap; convergence) types are represented for the most part by regions belonging to Central Russia - the Chernozem, Central, North Caucasian and Volga economic regions, the west of the Volga-Vyatka region (Nizhny Novgorod region, Mordovia). From the Asian part of the country, only two regions belong to it: the Altai Territory 
and the Khanty-Mansi Autonomous Okrug. Starting from 2010, the $e_{0}$ curves for these two types merge and lie above the average Russian values, while the growth rates of $e_{0}$ in type VI, which is characterized by convergence, in 2003-2018 were higher than in type V, and were inferior only to type III, in which center-peripheral convergence was also observed during the indicated period, but with a higher initial level of center-peripheral inequality.

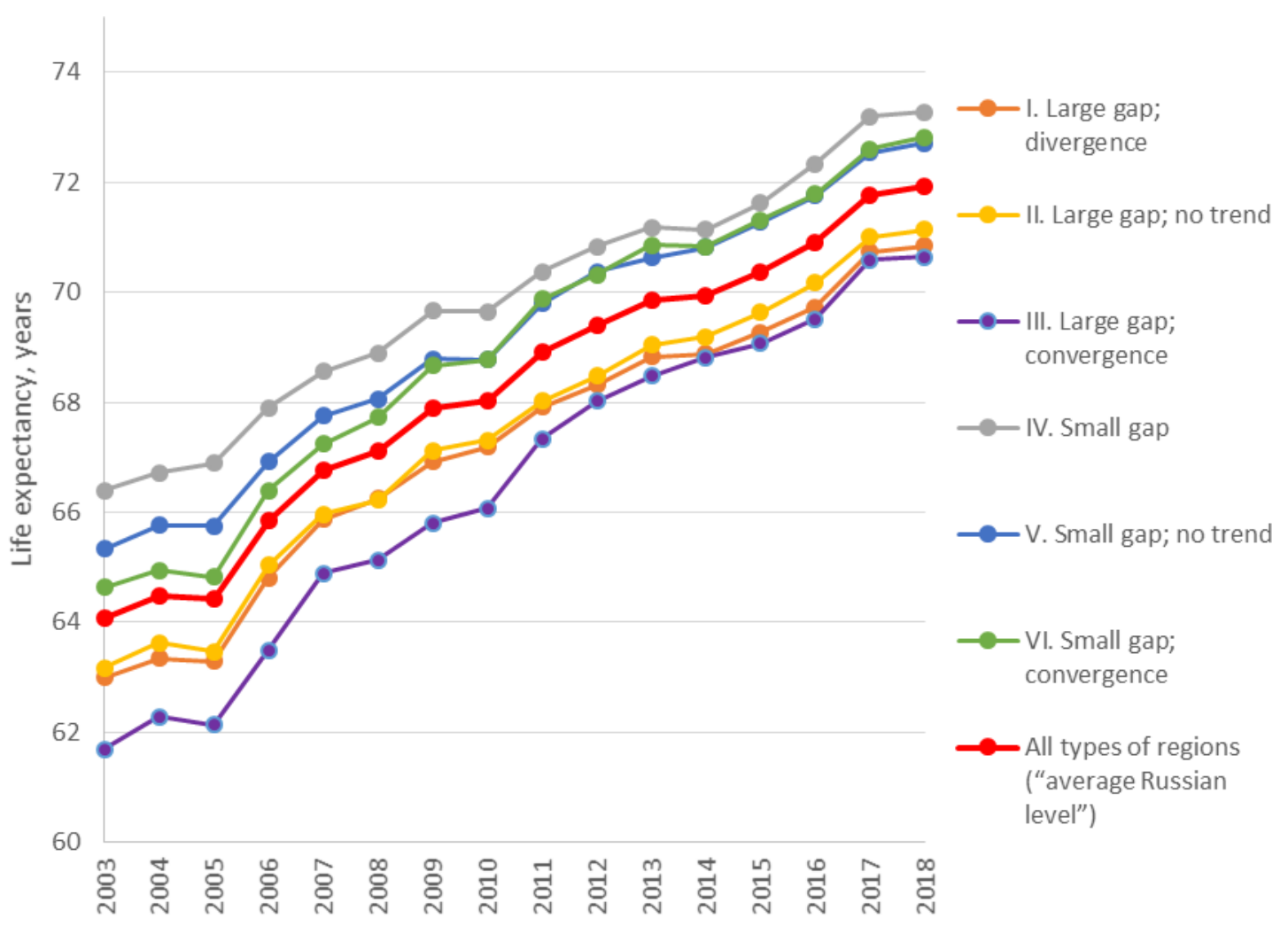

Figure 4. Life expectancy at birth depending on the type of regions, in years, 2003-2018

Inequality in the mortality rate between the types of regions, expressed in terms of the value of the standard deviation, decreased in 2006-2014, but in recent years the convergence has practically stopped. The distance between the top three curves on the graph (Figure 4), uniting the regions with a low gap in $e_{0}$, and the three bottom curves, reflecting the regions where, on the contrary, it is high, since 2015 has been about 2 years. This, in turn, is equivalent to the total increase in $e_{0}$ in Russia over 5 calendar years ${ }^{6}$. At the same time, the range of inequality in $e_{0}$ at the periphery between all six types of regions is significantly higher than between their centers: in 2018, 3.2 and 1.9 years, respectively. Such a situation is to be expected, given that the capitals of the regions are a more homogeneous group of entities, including only cities with a population of over 100 thousand people, while the "periphery", at least in terms of the settlement structure, is highly differentiated depending on the specific region. Thus, interregional inequality in mortality in Russia, including its "southwestern/northeastern gradient", is determined, for the most part, by inequality in mortality on the "periphery" of Russian regions, and not in their centers.

\footnotetext{
${ }^{6}$ The average annual growth rate of $e_{0}$ in Russia at the current stage of mortality reduction fluctuates at the level of 0.4-0.5 years (depending on the year of the beginning of the stage).
} 
So, the value of the gap in $e_{0}$ between the center and the rest of the region is determined almost entirely by the mortality rate at the periphery, while the direction of change in the gap depends on the dynamics of $e_{0}$ both in the center and at the periphery. In regions where the gap in $e_{0}$ is decreasing, this is primarily due to the catching up rate of decrease in the mortality rate outside the center. In contrast, the regions characterized by divergence in the mortality rate between the center and the periphery are distinguished by higher values and growth rates of $e_{0}$ in the capitals. In addition, in the IV-VI types of regions, where the center-peripheral gap is lower than the national average, the $e_{0}$ values are higher and, conversely, in the I-III types, the $e_{0}$ values are lower than the national average and the gap is higher. At the same time, the fastest growth in life expectancy in 2003-2018 at the level of the entire region (without dividing into center and periphery) was shown by types III and VI, where there was a convergence in mortality rates between the center and the periphery.

\section{REGIONS OF RUSSIA WITH A HIGH LEVEL OF CENTER-PERIPHERAL DIFFERENCES IN LIFE EXPECTANCY: THE ROLE OF AGE AND CAUSES OF DEATH}

Reducing the life expectancy lag of regions' periphery from their centers would benefit the harmonious spatial development of the country and should be one of the main priorities of the public health system: all residents of Russia, regardless of their place of residence, are guaranteed the "right to health".

The problem of center-peripheral inequality in the mortality rate in Russia is especially acute in the first three types of regions (Appendix table). In 2003-2018, of the 36 regions of the Russian Federation where the gap in $e_{0}$ between the center and the rest of the region exceeded the average Russian level, only 6 showed a tendency to its reduction. In 2018, life expectancy at birth for men in the centers of these regions was 3.3 years higher than in other localities, for women 2.7 years higher (Figure 5). Decomposing the center-periphery gap in mortality by age group and cause of death will help to identify the key "problem points" responsible for the periphery's lag in life expectancy.

As shown in Figure 5, the lag of men in $e_{0}$ in the periphery is a consequence of their higher mortality from external causes at younger (15-39 years old) and middle (40-54 years old) working ages, as well as, to a lesser extent, of the higher mortality rate from diseases of the circulatory system, primarily from ischemic heart disease and CVD, in middle (40-64 years old) and elderly (65 years and older) ages. 


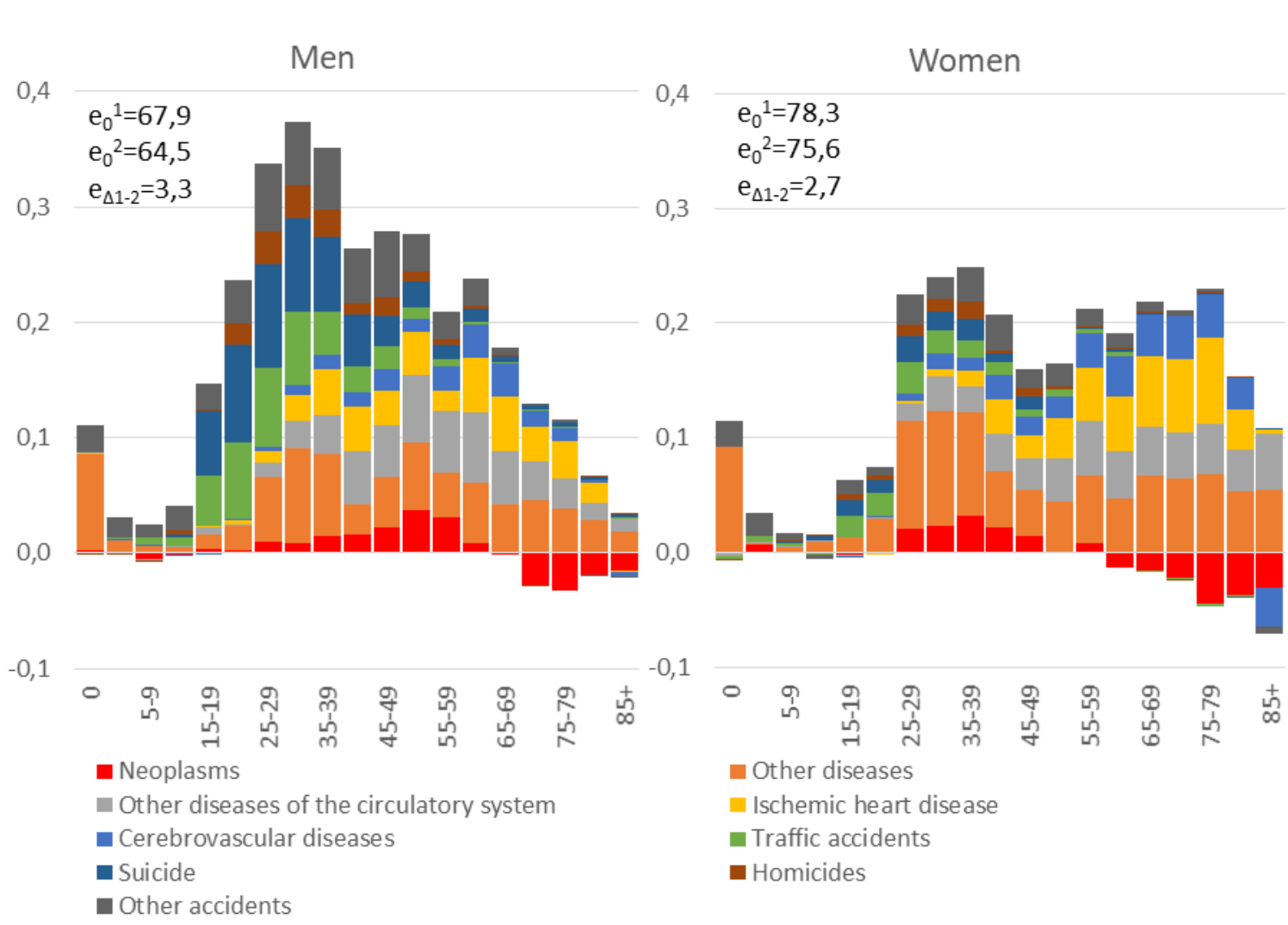

Figure 5. Contribution of age groups and causes of death to differences in life expectancy at birth between regional centers (1) and the periphery (2) for men and women, 2018

The lower mortality rate from diseases of the circulatory system in middle and old ages in regional centers explains about half of their advantage over other settlements in the life expectancy of women. Like the male population, the female population outside the regional capitals is characterized by a more pronounced "excess mortality bump" from external causes of death and other diseases (infections, diseases of the respiratory and digestive systems) at a relatively young age (25-44 years). "Rejuvenation" of mortality from such causes of death as tuberculosis, HIV infection, pneumonia, cirrhosis (including alcoholic) and cardiomyopathy (including alcoholic etiology) may, according to Ivanova et al., speak of "a marginalization of society, a decline in the "quality" of the population, an expanding class of persons who are poorly socially adapted and maladapted" (Ivanova, Mikhailov, Semenova 2009: 41).

It is noteworthy that the registered mortality from neoplasms in the centers of the regions is lower than in the rest of their territory at young and middle ages, but higher in old age, and the older the age group, the higher the mortality gap not in favor of the centers. In our opinion, which coincides with the position of our colleagues (Danilova 2015; Papanova, Shkolnikov, Timonin 2019), this fact not only does not mean a more favorable situation regarding the level of oncological mortality in the periphery, but, on the contrary, may indicate a lack of both pre- and post-mortem cancer diagnosis in older persons far from major cities.

The table shows the ratio of standardized mortality rates (SMRs) in the center and in the periphery from individual classes and causes of death for 36 regions distinguished by a significant center-peripheral gap in $e_{0}$. Women living in regional centers, as the population with the lowest mortality rate, were selected as the "reference group". 
Table. Ratios of standardized mortality rates, 2018

\begin{tabular}{|c|c|c|c|c|}
\hline Cause of death & $\begin{array}{l}\text { Women of the } \\
\text { periphery to } \\
\text { women of the } \\
\text { center }\end{array}$ & $\begin{array}{l}\text { Men of the center } \\
\text { to women of the } \\
\text { center }\end{array}$ & $\begin{array}{l}\text { Men of the } \\
\text { periphery to } \\
\text { women of the } \\
\text { center }\end{array}$ & $\begin{array}{l}\text { Men of the } \\
\text { periphery to men } \\
\text { of the center }\end{array}$ \\
\hline $\begin{array}{l}\text { Some infectious and parasitic } \\
\text { diseases }\end{array}$ & 1.24 & 2.61 & 2.73 & 1.05 \\
\hline Malignant neoplasms (MN) & 0.93 & 2.01 & 1.93 & 0.96 \\
\hline $\mathrm{MN}$ of the digestive system & 0.91 & 2.14 & 1.92 & 0.89 \\
\hline $\begin{array}{l}\text { MN of the respiratory } \\
\text { system }\end{array}$ & 1.01 & 6.81 & 7.82 & 1.15 \\
\hline $\begin{array}{l}\text { MN of the genital and } \\
\text { urinary organs }\end{array}$ & 1.06 & 1.74 & 1.52 & 0.88 \\
\hline Other MN & 0.86 & 1.06 & 0.95 & 0.89 \\
\hline $\begin{array}{l}\text { Diseases of the nervous } \\
\text { system }\end{array}$ & 1.18 & 1.40 & 1.72 & 1.23 \\
\hline $\begin{array}{l}\text { Diseases of the circulatory } \\
\text { system (CVD) }\end{array}$ & 1.10 & 1.94 & 2.16 & 1.11 \\
\hline Ischemic heart disease & 1.04 & 2.10 & 2.20 & 1.05 \\
\hline Cerebrovascular diseases & 1.02 & 1.60 & 1.67 & 1.04 \\
\hline Other CVD & 1.54 & 2.18 & 3.24 & 1.48 \\
\hline $\begin{array}{l}\text { Diseases of the respiratory } \\
\text { system }\end{array}$ & 1.21 & 3.74 & 4.75 & 1.27 \\
\hline $\begin{array}{l}\text { Diseases of the digestive } \\
\text { system }\end{array}$ & 1.23 & 1.87 & 2.19 & 1.17 \\
\hline Senility & 4.24 & 0.91 & 4.35 & 4.81 \\
\hline Unknown causes & 1.05 & 3.74 & 3.63 & 0.97 \\
\hline External causes & 1.52 & 4.17 & 6.19 & 1.49 \\
\hline Traffic accidents & 1.92 & 2.94 & 6.14 & 2.09 \\
\hline Suicide & 2.09 & 5.59 & 12.42 & 2.22 \\
\hline Homicide & 1.91 & 3.60 & 6.63 & 1.84 \\
\hline $\begin{array}{l}\text { Harm with undetermined } \\
\text { intent }\end{array}$ & 1.06 & 4.17 & 4.44 & 1.06 \\
\hline Other accidents & 1.69 & 4.32 & 6.52 & 1.51 \\
\hline Other diseases & 1.26 & 1.26 & 1.35 & 1.07 \\
\hline All causes of death & 1.19 & 2.07 & 2.41 & 1.17 \\
\hline
\end{tabular}

The largest gaps in SMR were from external causes of death: the mortality rate from them in the periphery in 2018 was 1.5 times higher than in the centers for both men and women. The mortality rate from traffic accidents in men was 2.1 times higher outside the regional centers, from homicides - 84\% higher, and from suicides - 2.2 times higher than in the capitals of the regions, while mortality from suicides of men in the periphery was almost 12.5 times higher than the corresponding indicator for women in the centers.

There are also "other diseases of the circulatory system (CVD)", the SMR from which is higher outside the regional centers than in the centers, by 48 and $54 \%$ for men and women, respectively. Differences in mortality from other CVD are primarily due to differences in mortality from cardiomyopathy of explicit and implicit alcoholic etiology (Ivanova, Semenova, Dubrovina 2004). In addition, outside the regional capitals, the mortality rate from "senility" is 4-5 times higher than in the centers, which is usually attributed to the so-called "garbage causes of death", when the real cause of death has not been established (Ivanova et al. 2013). The abuse of "senility" as a cause of death also indirectly testifies to the low quality of pre- and post-mortem diagnosing of diseases in the elderly population (over 80 years old). 


\section{WHAT MIGHT DETERMINE THE SPATIAL DIFFERENCES IN MORTALITY RATES?}

The current stage of sustainable growth in life expectancy in Russia has embraced not only the centers of the regions, but also their periphery. However, the rate of decrease in the mortality rate in the centers and other settlements, as well as the size of the gap in $e_{0}$ between them at the time of the start of the study, differ significantly across the regions. As a result, while in some regions the growth in life expectancy was accompanied by convergence in the mortality rate between the center and the rest, in others the advantage of the centers only increased.

Differences in mortality rates depend both on conditions at the macro level, or the "context" of the territory (in other words, the "environmental effect"), and on differences at the micro level, in the socio-demographic characteristics of specific inhabitants (Cummins et al. 2007). If the "environmental effect" affects the entire population of a territory, then individual characteristics may not be directly related to the place of residence, but the unevenness in their distribution between inhabitants of different territories will certainly affect the aggregate mortality rates in them.

The most important socio-demographic characteristics that affect human life expectancy include education level, income level, professional status, marital status, ethnicity, religion, etc. (Marmot, Shipley, Rose 1984; Valkonen 1992; Mackenbach et al. 2003 ; Von Gaudecker, Scholz 2007). All of them to one degree or another determine the lifestyle and behavior of an individual in relation to his health and exposure to risk factors: smoking, alcohol and drug abuse, unhealthy diet, low physical activity, hypertension, etc.

The environmental effects include spatial differences in socio-economic, political and environmental conditions, in access to infrastructure (primarily to the health care system, including emergency medical care), and in the quality of housing (Diez-Roux 2002). However, the contextual effect is usually reflected in many individual characteristics. Thus, the level of household income is higher where there are highly paid jobs; the educational and professional composition of the population and the direction of migration flows also depend on the level of development of the local economy.

Thus, a higher level of socio-economic development or other factors attractive for migration and residence (climate, a well-developed infrastructure, including leisure and education) form a healthier population with a higher life expectancy. Conversely, in regions with unfavorable social and economic conditions, a culture of anomie can emerge, contributing to the spread of unhealthy lifestyles and high mortality rates (Shaw, Dorling, Mitchell 2002).

\section{IN RUSSIA, THE MIGRATION FLOW IS DIRECTED FROM THE PERIPHERY OF THE REGIONS TO THEIR CENTERS}

Despite the depopulation that affected most of the country from 2000 to 2010, many regional capitals not only preserved, but even increased their population. As a result, in 2003-2018 the proportion of the population living in regional centers in the total population steadily increased (Figure A1 of the Appendix). This is partly due to the more favorable ratio of deaths and births in 
the centers due to the younger age structure in them, but the main source of growth in such cities is the influx of migrants, both foreign and domestic. Moreover, the main suppliers of internal migrants to regional centers are, as a rule, other settlements of the same region (Karachurina, Mkrtchyan 2016).

Migration flows directed from the periphery of the regions to their centers not only contribute to the concentration of the population in a limited number of cities and the "desertification" of the periphery, but also lead to the "deterioration" of the structure of the population in terms of health in territories losing population. According to the "healthy migrant" theory, migration is associated with positive selection for health, that is, the mortality rate among migrants is lower than among the receiving population, as well as among the sending population (Razum, Zeeb, Rohrmann 2000).

Therefore, it can be assumed that the dynamics of the center's share in the region's population will be directly related to the direction and rate of change in the center-peripheral gap in $e_{0}$. Thus, the highest increase (over 7 percentage points) in the share of the center in the population of the entire region between 2003 and 2018 was noted in Tyumen, Kirov and Sakhalin regions, in Yakutia, Karelia, Buryatia and the Krasnoyarsk Territory - regions which are characterized by a significant center-peripheral gap in $e_{0}$. In general, the size of the increase in the share of centers in the population of the regions between 2003 and 2018 explains about $40 \%$ of the variance in the size of the gap in $e_{0}$ between the centers and other settlements in 2018 (Figure A2 of the Appendix).

Since most universities are located in regional centers, educational migration (relocation of school and college graduates in order to obtain higher education) is an important component of the center-peripheral migration flows in Russia. At the same time, educational migration makes a significant contribution to increasing the quality of human capital (the share of people with higher education in the population) in the centers at the expense of the periphery.

\section{THE SHARE OF THE POPULATION WITH HIGHER EDUCATION IN THE CAPITALS OF RUSSIAN REGIONS IS TWICE AS HIGH AS OUTSIDE OF THEM}

In the USSR, and then in Russia, the life expectancy of men and women with higher education significantly exceeded the corresponding indicators for less educated groups of the population (Pyankova, Fattakhov 2017). Moreover, the differentiation of $e_{30}{ }^{7}$ by level of education grew constantly from estimates for 1979 to estimates for 2015, mainly due to an increase in the gap in life expectancy of the population with higher education (Kharkova, Nikitina, Andreev 2017).

People with higher education are more likely to practice self-preserving behavior (as opposed to risky ones) and also have better skills of social adaptation, especially during crises (Shchur 2019). The burden of death from injuries and so-called alcohol-related causes of death is much less pronounced among Russians with higher education (Shkolnikov et al. 2006). Our analysis of the differences in the mortality rate between regional centers and other settlements

7 Life expectancy at the age of 30 (as a rule, a person's level of education rarely changes after age 30 ). 
showed that in the latter it is higher in young and middle working ages from external causes of death and some diseases, which indicate a low social adaptation of the deceased.

The 2010 census showed that in all surveyed regions, the share of the population with a tertiary level of education was higher in the regional center (Rosstat 2012). Thus, the share of the population with higher education in the centers, on average for 67 regions, is $31.6 \%$, while outside the centers it is $16.5 \%$ - a nearly twofold advantage of regional capitals. Taking into account the observed differentiation of longevity by educational groups in Russia, it is fair to assume that the gap in $e_{0}$ between the centers and the periphery is largely due to differences in the educational structure of their population.

\section{LIMITATION OF THE WORK}

Although some observations made by us regarding the reasons for the presence of a centerperipheral gap in life expectancy within the regions of Russia may be applicable to the analysis of interregional differences in the magnitude and direction of changes in the center-peripheral gap, our work does not contain a detailed analysis of socio-economic and/or physical and geographical determinants of interregional diversity and the spatial picture of the different types of regions we have identified.

\section{Conclusion}

During the study period (2003-2018), in the overwhelming majority of regions of Russia life expectancy at birth in regional centers was higher than in other settlements. At the same time, in 2003-2011 there was a trend towards an increase in the advantage of centers which was replaced in 2012 by a trend towards convergence in the mortality rate. However, it will be possible to say for sure that life expectancy indicators in the centers and on the periphery of Russian regions are converging only after the next population census. Although in 2011 the principle of registering migration in Russia was changed, leading to a significant increase in the number of registered migrants coming to the attention of domestic statistics, we cannot completely exclude the possibility that the 2021 census, like the 2010 census, will show an overestimation of the current population in the "periphery" and an underestimation in the "centers". In this case, the actual gap in $e_{0}$ between the regional centers and other settlements will be higher than the calculated one.

The magnitude of the gap in $e_{0}$ between the center and the rest of the region largely depends on the mortality rate at the periphery, while the direction of change in the gap depends on the dynamics of $e_{0}$ both in the center and at the periphery. In regions where the gap in $e_{0}$ is decreasing, this is primarily due to the catching up rate of the decrease in mortality outside the center. In contrast, the regions which are characterized by divergence in the mortality rate between the center and the periphery are distinguished by higher values and growth rates of $e_{0}$ in the capitals. In addition, in the IV-VI types of regions, where the center-peripheral gap is lower than the national average, the $e_{0}$ values are higher and, conversely, in the I-III types they are lower than the national average and the gap is higher. At the same time, the fastest growth in life expectancy in 2003-2018 at the level of the entire region (without dividing into the center and the periphery) was 
in type III and VI regions, where there was a convergence in mortality rates between the center and the periphery.

The gap in $e_{0}$ for men, as well as the change in this indicator over time, is mainly determined by the difference in mortality rates at young and middle (25-54 years) ages. Differentiation in mortality rates of women in this age group between the centers and the periphery is also important, but somewhat less than for men. Among the causes of death that determine the lag of the periphery from the centers in this age group are, above all, external causes of death, but also include diseases such as cardiomyopathy, tuberculosis, cirrhosis and some others indicating a rather marginal lifestyle of the deceased and their dropping out of society. It seems that, due to the more favorable educational structure, as well as the selective effect of migration, the share of the "marginal" population in the regional centers is lower than in the periphery. Thus, the differences in the mortality rate at young and middle ages between the centers and other settlements can be explained by the differences in the socio-demographic characteristics of their inhabitants. At the same time, the lower mortality rate of older people from chronic diseases in the centers is a consequence of the more developed healthcare system in them.

If geographical differences in mortality rates are primarily due to socio-economic differentiation of space, can full convergence be achieved only through measures affecting the development of the healthcare system and/or other public health initiatives? In other words, is it possible to eradicate the center-peripheral gap in $e_{0}$ in Russia while maintaining spatial inequality in the level of socio-economic development? Taking Germany as an example, we see how effective public health policies aimed at smoothing spatial differences in mortality rates have minimized the gap in mortality rates between the "old" and "new" federal states, even if a tangible heterogeneity of socio-economic conditions persists (van Raalte et al. 2020).

\section{ACKNOWLeDgments}

The authors are grateful to the anonymous reviewers whose comments, in our opinion, made it possible to significantly improve the manuscript of the article.

\section{REFERENCES}

Andreev E.M. (1979). Length of life in the USSR: A differential analysis. In E. Andreev, A. Vishnevski (Eds.), Length of life: Analysis and modelling. Moscow: Statistika. (In Russ).

Andreev E.M. (1982). The method of components in the analysis of length of life. Vestnik Statistiki, 9, 42-47. URL: http://www.demoscope.ru/weekly/knigi/andreev/andreev.pdf (In Russ).

Andreev E.M. (2012). On accuracy of Russia population censuses results and level of confidence in different sources of information. Statistical Issues, 11, 21-35. URL: http://www.demoscope.ru/weekly/2013/0549/analit01.php (In Russ).

Andreev E.M., Kvasha E.A., Khar'kova T.L. (2006). Special points on the mortality map. In A.G. Vishnevsky (Ed.), Naselenie Rossii 2003-2004. Odinnadtsatyy-dvenadtsatyy ezhegodnyy demograficheskiy doklad (pp. 298-305) [Russia's Population in 2003-2004. 1112 Annual Demographic Report]. Moscow: Nauka. (In Russ). 
Center for Demographic Research. (2018). Russian Fertility and Mortality Database. Retrieved from http://www.demogr.nes.ru/index.php/ru/demogr_indicat/data (data downloaded on 15.03.2020).

Cummins S., Curtis S., Diez-Roux A.V., Macintyre S. (2007). Understanding and representing 'place' in health research: A relational approach. Social Science \& Medicine, 65(9), 18251838. DOI: 10.1016/j.socscimed.2007.05.036.

Danilova I. (2015). Problems of the quality of cause-specific mortality statistics at advanced ages. Advances in Gerontology, 3, 409-414. URL:

https://www.hse.ru/data/2018/10/11/1155689100/\%D0\%94\%D0\%B0\%D0\%BD\%D0\%B8\% D0\%BB\%D0\%BE\%D0\%B2\%D0\%B0.pdf (In Russ).

Diez Roux A.V. (2002). A glossary for multilevel analysis. Journal of Epidemiology and Community Health, 56(8), 588-594. DOI: 10.1136/jech.56.8.588.

Federal State Statistics Service (Rosstat) (FSSS). (2012). All-Russian population census 2010. URL: https://www.gks.ru/free_doc/new_site/perepis2010/croc/perepis_itogi1612.htm (In Russ).

Ivanova A., Semenova V., Dubrovina E. (2004). Chto skryvayetsya za "drugimi boleznyami serdtsa"? [What is hidden behind 'other heart diseases'?]. Demoskop Weekly, 181-182. URL: http://www.demoscope.ru/weekly/2004/0181/tema02.php (In Russ).

Ivanova A.E. Mikhaylov A.YU., Semenova V.G. (2009). Poteri prodolzhitel'nosti i kachestva zhizni naseleniya Rossii [Loss of length and quality of life of Russian population]. Narodonaseleniye, 3, 40-49. URL: https://cyberleninka.ru/article/n/poteri-prodolzhitelnosti-ikachestva-zhizni-naseleniya-rossii (In Russ).

Ivanova A.E., Sabgayda T.P., Semenova V.G., Zaporozhenko V.G., Zemlyanova E.V., Nikitina S.YU. (2013). Factors distorting structure of death causes in working population in Russia. Social aspects of population health, 4(32). URL: http://vestnik.mednet.ru/content/view/491/30/ (In Russ).

Karachurina L.B., Mkrtchyan N.V. (2016). Regional'nyye tsentry Rossii v fokuse migratsii [Regional centers of Russia in migration's focus]. In V. Kotlyakov, V.N. Streletskiy, O.B. Glezer, S.G. Safronov (Eds.), Problemy regional'nogo razvitiya Rossii (pp. 209-233). Moscow: Izdatel'skiy dom «Kodeks». (In Russ).

Khar'kova T.L., Nikitina S.YU., Andreev E.M. (2017). Dependence of life expectancy on the education levels in Russia. Statistical Issues, 8, 61-68. URL: https://voprstat.elpub.ru/jour/article/view/546 (In Russ).

Leksin V.N. (2009). Goroda vlasti: administrativnyye tsentry Rossii [Cities of Power: Administrative Centres of Russia]. Mir Rossii: Sotsiologiya, etnologiya, 18(1), 3-33. URL: https://mirros.hse.ru/article/view/5127 (In Russ).

Mackenbach J.P., Bos V., Andersen O., Cardano M., Costa G., Harding S., Reid A., Hemström Ö., Valkonen T., Kunst A.E. (2003). Widening socioeconomic inequalities in mortality in six Western European countries. International Journal of Epidemiology, 32(5), 830-837. DOI: 10.1093/ije/dyg209.

Marmot M. (2006). Social determinants of health inequalities. Lancet, 365(9464), 1099-1104. DOI: $10.1016 / \mathrm{s} 0140-6736(05) 74234-3$.

Marmot M.G., Shipley M.J., Rose G. (1984). Inequalities in death-specific explanations of a general pattern? Lancet, 1(8384), 1003-1006. DOI: 10.1016/s0140-6736(84)92337-7. 
Mkrtchyan N.V. (2012). Issues of acquiring population in certain age groups during the Census of 2010: The reasons for the deviations from the expected counts. In M. B. Denisenko (Ed.), Demographic aspects of socio-economic development (pp. 197-214). Moscow: MAKS Press (In Russ).

Nefyodova T., Treyvish A. (2020). Polarization and shrinkage of active space in the core of Russia: trends, problems and possible solutions. Demographic Review, 7(2), 31-53. https://doi.org/10.17323/demreview.v7i2.11138 (In Russ).

Novosel'skij S.A. (1911). O razlichiyah v smertnosti sel'skogo i gorodskogo naseleniya Evropejskoj Rossii [Differences in mortality between the rural and urban population of European Russia]. Obshchestvennyj vrach, 4. (In Russ).

Novosel'skij S.A. (1916). Smertnost' i prodolzhitel'nost' zhizni v Rossii [Mortality and life expectancy in Russia]. Saint Petersburg: Tipografiya MVD. URL: http://www.demoscope.ru/weekly/knigi/novoselskij/novoselskij_1916.pdf (In Russ).

Papanova E., Shkolnikov V., Timonin S. (2019). Distinctive features and components of mortality decrease in Moscow in 1989-2017. Demographic Review, 6(1), 50-103. https://doi.org/10.17323/demreview.v6i1.9113 (In Russ).

Pyankova A.I., Fattakhov T.A. (2017). Smertnost' po urovnyu obrazovaniya v Rossii [Mortality by level of education in Russia] // HSE economic journal. 21(4), 623-647. URL: https://ej.hse.ru/data/2017/12/28/1160683586/\%D0\%9F\%D1\%8C\%D1\%8F\%D0\%BD\%D0 \%BA\%D0\%BE\%D0\%B2\%D0\%B0.pdf (In Russ).

Razum O., Zeeb H., Rohrmann S. (2000). The 'healthy migrant effect' - not merely a fallacy of inaccurate denominator figures. International Journal of Epidemiology, 29(1), 191-192. DOI: 10.1093/ije/29.1.191.

Sen A. (1998). Mortality as an Indicator of Economic Success and Failure. The Economic Journal, 108(446), 1-25. DOI: 10.1111/1468-0297.00270.

Shaw M., Dorling D., Mitchell R. (2002). Health, Place and Society. Singapore: Pearson.

Shchur A. (2019). Education level as a factor in demographic forecasting. Demographic Review, 6(2), 204-208. https://doi.org/10.17323/demreview.v6i2.9878 (In Russ).

Shkolnikov V.M. (1987). Geographical factors of length of life. Izvestiya AN SSSR. Geographical Series, 3(12), 35-44. (In Russ).

Shkolnikov V.M., Andreev E., Jasilionis D., Leinsalu M., Antonova O., McKee M. (2006). The changing relation between education and life expectancy in central and eastern Europe in the 1990s. Journal of Epidemiology and Community Health, 60(10), 875-881. DOI: 10.1136/jech.2005.044719.

Timonin S., Danilova I., Andreev E., Shkolnikov V.M. (2017). Recent mortality trend reversal in Russia: are regions following the same tempo? European Journal of Population, 33(1), 733 763. DOI: $10.1007 / \mathrm{s} 10680-017-9451-3$.

Timonin S., Jasilionis D., Shkolnikov V., Andreev E.M. (2020). New perspective on geographical mortality divide in Russia: a district- level cross- sectional analysis, 2008-2012. Journal of Epidemiology and Community Health, 74(2), 144-150. DOI: 10.1136/jech-2019213239.

Valkonen T. (1992). Trends in regional and socio-economic mortality differentials in Finland. International Journal of Health Sciences, 3(3-4), 157-166. URL: https://pubmed.ncbi.nlm.nih.gov/12345858/ 
van Raalte A.A., Klüsener S., Oksuzyan A., Grigoriev P. (2020). Declining regional disparities in mortality in the context of persisting large inequalities in economic conditions: the case of Germany. International Journal of Epidemiology, 49(2), 486-496. DOI: 10.1093/ije/dyz265

Vasin, S., Costello C.A. (1997). Spatial, age, and cause-of-death patterns of mortality in Russia, 1988-1989. In J.L. Bobadilla, C.A. Costello, F. Mitcell (Eds.), Premature Death in the New Independent States (pp. 66-119). Washington, DC: National Academies Press.

Vishnevsky A.G., Shchur A.E. (2019). Smertnost' i prodolzhitel'nost' zhizni v Rossii za polveka [Mortality and life expectancy in Russia for half a century]. Orgzdrav: novosti, mneniya, obucheniye, 5(2), 10-21. DOI: 10.24411/2411-8621-2019-12003. (In Russ).

Von Gaudecker H., Scholz, R. (2007). Differential mortality by lifetime earnings in Germany. Demographic Research, 17, 83-108. DOI: 10.4054/demres.2007.17.4

Zakharov S.V. (2019). Naseleniye Rossii 2017: dvadtsat' pyatyy ezhegodnyy demograficheskiy doklad [Russia's population: 25 annual demographic report]. Moscow: Izdatel'skiy dom NIU VSHE. (In Russ). 


\section{APPENDIX}

Table. Types of regions ( $\mathrm{I}$ - VI) depending on the size of the gap in eo and the dynamics of its change in 2003-2018

\begin{tabular}{|c|c|c|c|c|c|c|c|}
\hline$\overline{\text { No. }}$ & Type & $\begin{array}{c}\text { Population, } \\
\text { millions, } \\
2018 \\
\end{array}$ & \begin{tabular}{|c|} 
Gap in \\
$\mathrm{e}_{0}, 2018$ \\
(in years) \\
\end{tabular} & $\begin{array}{c}\text { Number of } \\
\text { regions }\end{array}$ & $\begin{array}{l}\text { Composition } \\
\text { (regions) }\end{array}$ & $\begin{array}{l}\text { Coefficient of } \\
\text { regression* }\end{array}$ & P-value \\
\hline I. & $\begin{array}{l}\text { Large gap, } \\
\text { divergence }\end{array}$ & 24.79 & 3.6 & 15 & $\begin{array}{l}\text { Arkhangelsk, Buryatia, } \\
\text { Zabaikalsky, Irkutsk, Komi, } \\
\text { Kursk, Mari El, Novosibirsk, } \\
\text { Omsk, Rostov, Sakhalin, } \\
\text { Sverdlovsk, Tuva, Tyumen, } \\
\text { Yakutia }\end{array}$ & $\begin{array}{c}0.09 \\
(0.07 ; 0.11)\end{array}$ & 0.00 \\
\hline II. & $\begin{array}{l}\text { Large gap, no } \\
\text { clear trend }\end{array}$ & 23.50 & 3.4 & 5 & $\begin{array}{l}\text { Amur, Vladimir, Karelia, } \\
\text { Kemerovo, Kirov, } \\
\text { Krasnoyarsk, Kurgan, } \\
\text { Orenburg, Primorsky, Tomsk, } \\
\text { Udmurtia, Khabarovsk, } \\
\text { Khakassia, Chelyabinsk, } \\
\text { Chuvashia }\end{array}$ & $\begin{array}{c}0.00 \\
(-0.03 ; 0.04)\end{array}$ & 0.81 \\
\hline III. & $\begin{array}{l}\text { Large gap, } \\
\text { convergence }\end{array}$ & 6.39 & 3.2 & 6 & $\begin{array}{l}\text { Kamchatsky, Novgorod, Perm, } \\
\text { Pskov, Smolensk, Tverskaya }\end{array}$ & $\begin{array}{c}-0.14 \\
(-0.18 ;-0.10)\end{array}$ & 0.00 \\
\hline IV. & $\begin{array}{l}\text { Small gap, } \\
\text { divergence }\end{array}$ & 16.11 & 2.0 & 7 & $\begin{array}{l}\text { Astrakhan, Bashkiria, } \\
\text { Belgorod, Volgograd, } \\
\text { Voronezh, Murmansk, } \\
\text { Tatarstan }\end{array}$ & $\begin{array}{c}0.14 \\
(0.10 ; 0.18)\end{array}$ & 0.00 \\
\hline V. & $\begin{array}{l}\text { Small gap, no } \\
\text { clear trend }\end{array}$ & 19.65 & 1.3 & 13 & $\begin{array}{l}\text { Adygea, Altai, Vologda, } \\
\text { Kalmykia, Kostroma, Lipetsk, } \\
\text { Mordovia, Samara, Saratov, } \\
\text { Stavropol, Tula, Ulyanovsk, } \\
\text { Khanty-Mansi Autonomous } \\
\text { Okrug }\end{array}$ & $\begin{array}{c}0.00 \\
(-0.03 ; 0.03)\end{array}$ & 0.96 \\
\hline VI. & $\begin{array}{l}\text { Small gap, } \\
\text { convergence }\end{array}$ & 18.54 & 0.4 & 11 & $\begin{array}{l}\text { Bryansk, Ivanovo, } \\
\text { Kaliningrad, Kaluga, } \\
\text { Krasnodar, Nizhny Novgorod, } \\
\text { Oryol, Penza, Ryazan, } \\
\text { Tambov, Yaroslavl }\end{array}$ & $\begin{array}{c}-0.08 \\
(-0.19 ;-0.05)\end{array}$ & 0.00 \\
\hline & All regions & 109.00 & 2.3 & 67 & & $\begin{array}{c}0.01 \\
(-0.01 ; 0.03) \\
\end{array}$ & 0.25 \\
\hline
\end{tabular}

* - The 95\% confidence interval is indicated in parentheses; statistically significant coefficients are highlighted in bold. 


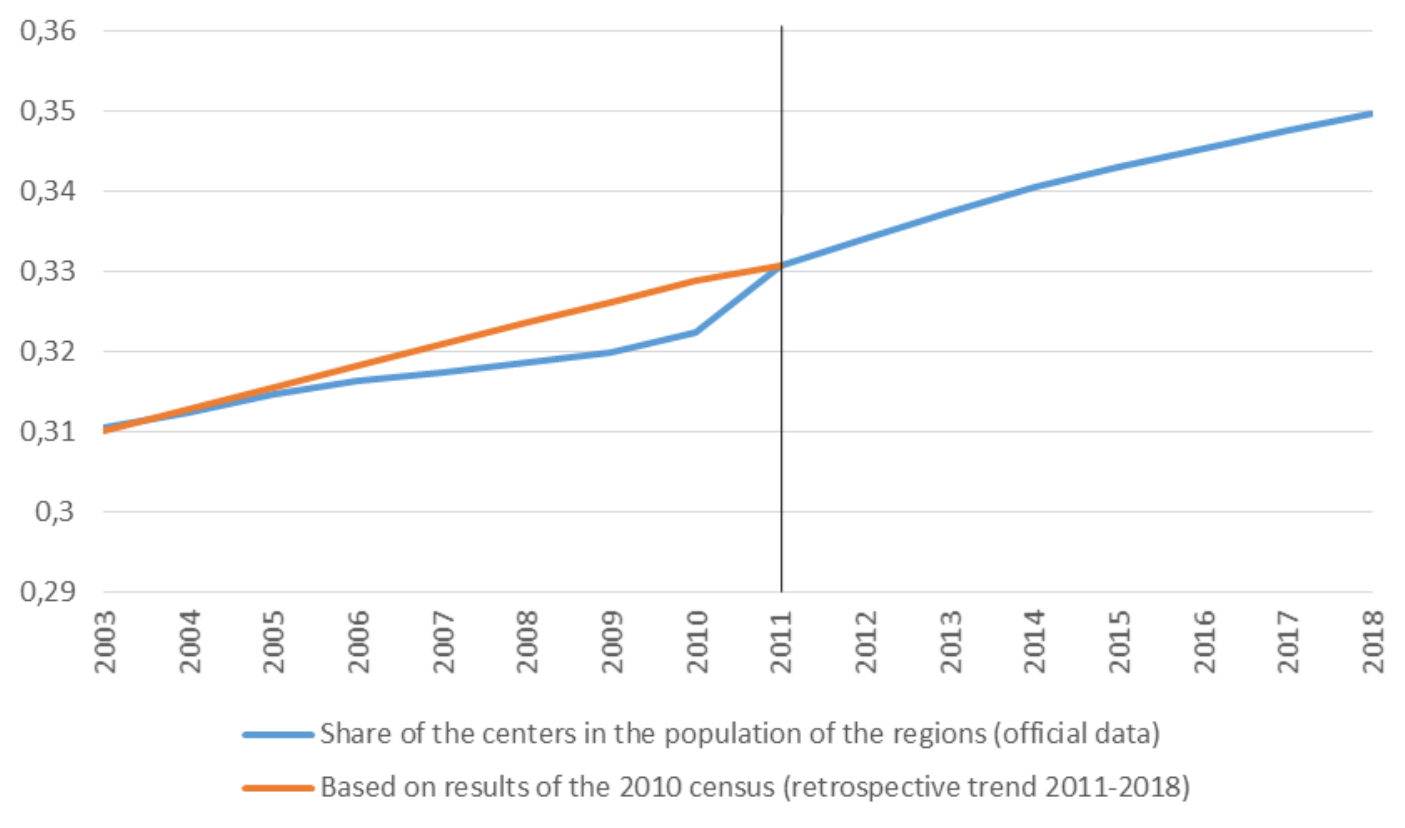

Figure A1. The share of the population in the Russian regions living in the regional center, $\%, 2003-2018$

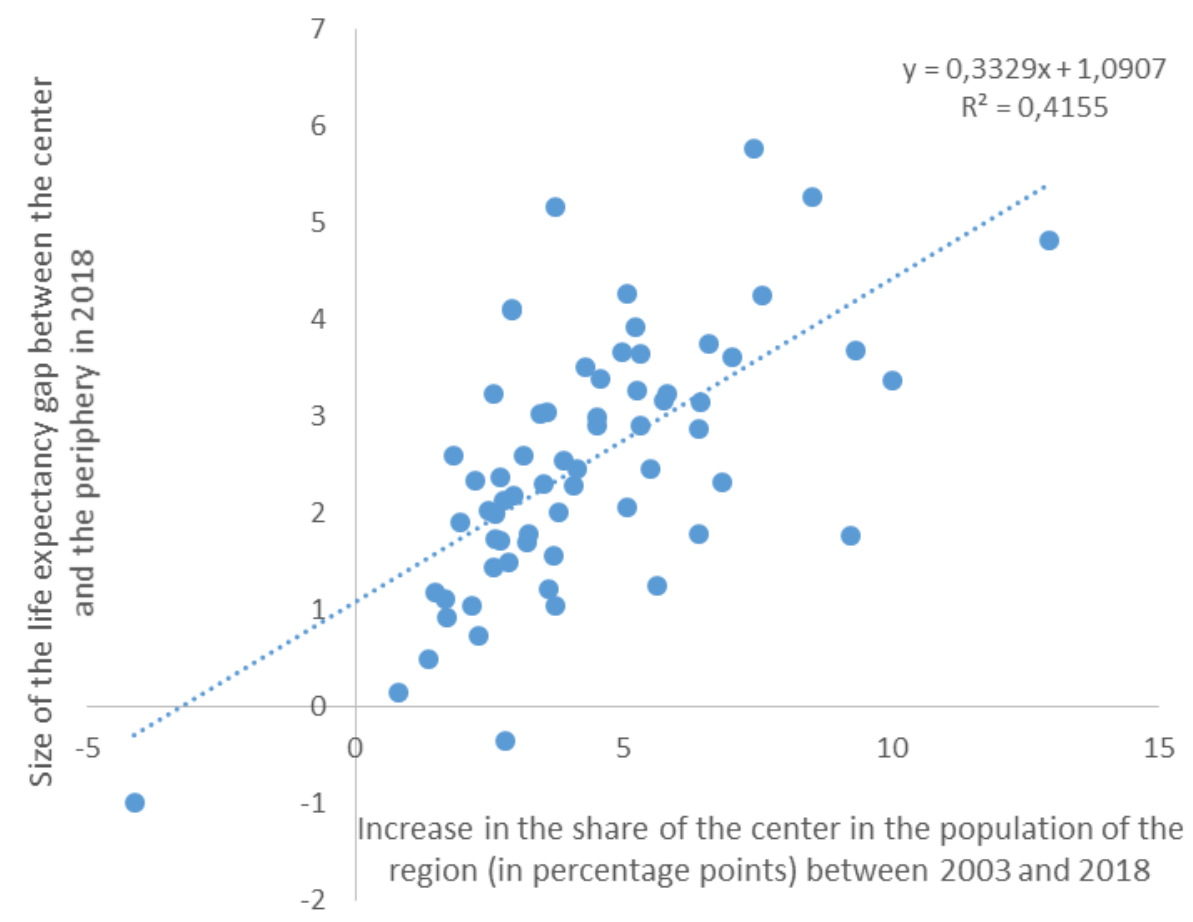

Figure A2. Impact of the increase in the share of the center in the population of the region between 2003 and 2018 on the size of the gap in e0 between the center and other settlements in 2018 